\title{
A Case Study on Psychological Capital and Teaching Effectiveness in Elementary Schools
}

\author{
J. H. Wang, Y. T. Chen, and M. H. Hsu
}

\begin{abstract}
- this research purpose is to study the current status of the psychological capital of elementary schools' teachers. By analyzing all aspects of situations caused by background variables, this research concludes the relationship from all aspects of factors which could affect the psychological capital and the teaching effectiveness. The survey is done by questionnaire, and sampling from elementary schools' teachers in the Chaiyi County in Taiwan and using stratified sampling from schools with teachers. In the end, based on the research, specific proposes are recommended as references for executives of education, related educators, and subsequent researchers.
\end{abstract}

Index Terms-Psychological capital, teaching effectiveness, self-efficacy, resiliency, teaching strategy.

\section{INTRODUCTION}

1990s, Taiwan 410 education reform movement, and it push the education reform. Such as the promotion of school-based management and the implementation of the nine-year curriculum, the twelve-year compulsory basic education, which is nothing more than in the pursuit of quality school performance, creating excellent quality of education. In 1999, National Compulsory Education Law Amendment that principals and directors select way from the assignment system to select the external system is in practice on performance responsibility. On the establishment of the teachers ' organizations, Educational Evaluation Committee and the Curriculum Development Committee, people focused on the high quality of education, and it makes the challenge of facing the talents competition both in and out of the school. The impact of the declining birthrate and a heterogeneous population structure derivative students discipline problems, the phenomenon of bullying, and it is inevitable teachers' physically and mentally exhausted, but less people pay attention to this part. In the Education reform, it's rarely to discuss on teachers' attitude. This article through discuss on the psychological capital, taking into account the inherent psychological attention, awareness, attitudes.

The High Impact Leader addressed by Avolio and Luthans [1] the book discusses psychological capital investment

Manuscript received September 22, 2013; revised November 24, 2013.

J. H. Wang is with the Graduate Institute of Educational Administration and Policy Development, National Chiayi University, No.85, Wunlong Village, Minsyong Township, Chiayi County 621, Taiwan (R.O.C) (e-mail: gloriawang2004@ mail.ncyu.edu.tw)

Y. T. Chen is with the Department of Mathematics Education, National Taichung University, No.140, Minsheng Rd., West Dist., Taichung City 40306, Taiwan (R.O.C.) (e-mail: ytchen@mail.ntcu.edu.tw ).

M. H. Hsu is with the Yiren Elementary School, No. 22, Pingding, Yiren Vil., Zhuqi Township, Chiayi County 604, Taiwan (R.O.C.) (e-mail:2661916@yahoo.com.tw) leaders and followers will bring competitive advantage to the Organization, and it also can strengthen the leader and followers, and it makes the entire organization become more successfully. Advocated the psychological capital can be used as a way to monitor, determine the extent of organization leaders and their subordinates the degree of development with their potential. In 2002, Seligman researched the topic of "The positive qualities of the development of human potential and virtue and so on" as his new perspective in the study was launched in academic studies "mental capital". The connotations of psychological capital are the degreed of self-efficacy and toughness reflect the level of teaching effectiveness, and there is significant merit to further empirical research.

Therefore, based on the above-mentioned study motivation, the main purpose of the study are as follows. First, the researchers try to understand Chiayi County elementary school teachers ' psychological capital and the effectiveness of teaching. Second, the researchers explore different background in Chiayi County teachers ' psychological capital and teachers ' teaching effectiveness. Third, the researchers try to explore the psychological capital of Chiayi County elementary school teacher effect on teachers ' teaching effectiveness. Forth, the researchers explore in Chiayi County on teaching effectiveness of elementary school teachers ' psychological capital forecast.

\section{LITERATURE REVIEW}

\section{A. Meaning of Psychological Capital and Related Theories}

Individual development of psychological capital is shown in the status of positive psychological [2]. Traditional economic capital, human capital and social capital studies, and based on the positive psychology and positive organizational behavior perspective, and regard psychological capital as "individuals is to the core of psychological factors, specific performance of the psychological state of positive organizational behavior standards, and it is beyond the human and social capital, and through targeted investment and development and it makes individuals gain a competitive advantage." Self-confidence, hope, optimism, resiliency those are four positive psychological states merged into the core concepts of a higher level, called psychological capital (Psychological Capital PsyCap) [3].

Positive organizational behavior (referred POB) starting from the micro level of the individual, and according to its definition of psychological capital, positive organizational behavior point out four measured standard are self-efficacy / 
confidence, hope, optimism, resiliency [2].

Psychological capital has two main areas of relevant theory: human capital theory and the theory of positive psychology (positive organizational behavior theory). In traditional economics, human capital theory refers to the resources for material production and revenue, the connotation of the modern capital physical capital extends to human capital.

Positive psychology researches focus on positive emotions and experiences, positive personality traits, positive psychological processes and so on. The Who Moved My Cheese by Spencer Johnson, proposed change of attitude and approach is also a forward, through the application positively oriented human resource advantage and psychological capacity, so that they can be measured, developed, repeating as the improvement of teachers ' teaching effectiveness.

The analysis of psychological capital factors and structure, and their theoretical basis of analysis found that despite the psychological connotation of capital raised different by different researchers, but scholars [4] discuss the meaning of psychological capital is as follows. First, based on the theories and research; the second, correct measurement; third, relatively unique in the organizational behavior; forth, state-like rather than trait-like, can be developed and changed; fifth, working on personal achievement and satisfaction about positive effects. The researchers will discuss more on the following four elements of psychological capital, self-efficacy, hope, optimism, and resiliency.

\section{B. Self-Efficacy}

Gist and Mitchell (1992) [5] believes that self-efficacy is the way to determine personal capacities, and use the way of stimulating, cognitive resources and ways of action in order to reach a future performance on specific tasks. Self-efficacy has decided that people selected behavioral tasks and the persistence and effort in the tasks. Therefore highly self-efficacy of teachers can be a positive impact on student achievement.

\section{1) Hope}

Traditional Psychotherapy focuses on the reduction and elimination of despair, rather than construction of hope that a positive attitude. Despair placing negative views put into mental at any time, but to ignore individual control as well as the results expected of self-fulfilling. Hope is the dynamic of results expectations and individual can affect the results in the expected path. Social Psychology Theories believe that hope is to reach the target, and want to reflect the upgrade possibility of achieving the target [6]. (Stotland, 1969)

\section{2) Optimism}

Optimism is the positive life attitude, and it represents the expectation of results [1].Tiger (1979) advocated that when the evaluators regard the future expectations or materiality as the need in the society, and he has interested and brought happiness, then this expectation associated attitude is optimistic[7]. Diener (1984) advocated that the optimism affect the physical and mental health and personal achievements deeply, and it's through learning [8].

\section{3) Rresiliency}

Resiliency is from the perspective of crisis to develop, and it focuses on adaptation, compression, and tolerance for frustration, relevant responses. Currently, the word "Resiliency" uses in the medical, education, counseling, social work and other related research.

\section{The Implications of Important Aspects of the Teachers' Teaching Effectiveness}

The purpose of teaching effectiveness is to improve student achievement. It makes scholars defined teaching effectiveness with different ways.

\section{1) Two orientations in teachers' teaching efficiency}

Today's' teachers' teaching efficiency pperformance trends from "effective teaching" and "teacher effectiveness" discuss perspective. It is described as below:

\section{a) Discuss from the view of "effective teaching"}

Teaching activities related to the elements and strategies and it needs to be well planned, and it is the interaction between teachers and students and to achieve valuable learning interactions. Teachers' effective teaching is a teaching qualification process performance, and it is from the teachers' outside angle degree, and to make good use of a complex and effective strategies to improve the way teachers effective teaching and learning, and it also promotes students' learning outcomes, and to achieve specific educational goals.

b) Discuss from the view of "teaching efficacy"

Bandura (1997) regards teaching efficacy as the capacity of an individual to finish the expectation of behavior in specific situations, and it includes the expectation of efficacy and the expectation of results [9]. The expectation of efficacy is the individual judgment in any kind of situations, and the expectation of results is the prediction of results to an individual.

\section{2) The Important aspects of teaching effectiveness}

The study of teachers' teaching effectiveness connotation with four dimensions, mastered by the connotation of teaching performance, and the research could explore more teachers' psychological capital to help improve teaching effectiveness, so as to achieve the educational goals. The significance alls include the following four important dimensions, as follows:

\section{a) The philosophy of teaching}

The teaching philosophy is based on teachers' professional knowledge and literacy, and practice in the teaching activities. The high-performance teachers have good self-efficacy beliefs with enthusiasm, and they can control the starting point of students' behavior, and arranged a suitable learning environment, enabling students to have meaningful and effective learning, and to achieve educational goals through the interaction of teaching.

\section{b) Multiple teaching strategies}

The researchers integrated theory of teaching and learning theory, teaching can make good use of motivation theory and multiple teaching strategies to incentive students' motivation and to focus students' attention. The use of different teaching media or method mastered questioning skills and good time management, and systematically present the teaching materials to enhance students' learning motivation and effectiveness. 


\section{c) Utilize teaching assessment}

The teaching assessment refers to a system of gathering information about student learning behavior and analyzes it. It's a re-qualification process which is giving value judgments based on the scheduled teaching objectives. That means the use of teaching assessment refers to teachers make good use of the adaptive multivariate assessment according to the teaching goals after teaching. Use the assessment of the effectiveness of learning to diagnose student learning problems, moderate adjustments teaching progress and teaching materials' degree of difficulty, the use of teaching assessment feedback, conducting remedial teaching to help students solve problems in a timely manner, and teaching in order to achieve the desired results.

\section{d) Class leadership}

Teachers use positive leadership to promote good classroom leadership and create a harmonious atmosphere for learning, the establishment of a harmonious teacher-student interaction, and actively caring motivate students to positive behavior, so you can predict student achievement and the helps for students learning. It makes students' thoughts, concept and behavior development and learning effectively. Then, it also enhances teaching effectiveness.

\section{RESEARCH METHODS AND DESIGN}

The objects of this study are teachers in Chiayi County's public elementary schools in 2010 school year. For the establishment of the questionnaire, the researchers made "the expert validity consulting Scale" after the completion of the first draft of the questionnaire, and respectively invited scholars and experts to examine and recommend the contents of the questionnaire, and based on the recommendations for revised. The final factor analysis and Cronbach's a analysis confirmed the questionnaire's reliability and effective degrees.

\section{A. Teachers' Psychological Capital Scale Items Analysis}

\section{1) Via the SPSS statistical analysis}

Researchers found that "elementary school teachers' psychological capital"'20 questions value t reached .000 level of significance, the question items and the total score correlation coefficients were greater than .30 , and after delete questions $\alpha$ coefficient do not reach the total reliability alpha value of .933 .

\section{2) Actor analysis of teachers' psychological capital scale}

Factor analysis is a potential structural analysis, and the purpose is to obtain the construct validity of the scale. In this study, statistical analysis determines the pre-test questionnaire suitability for factor analysis. First, researchers use Kaiser-Meyer-Olkin measure of sampling adequacy, $\mathrm{KMO}$ sampling to detect $\mathrm{KMO}$ value. If it reaches more than.70, the reseachers will do the analysis of the factors. We found that the overall teachers psychological capital Scale cumulative $70.073 \%$ of the total variance from the "Teachers psychological capital Scale" factors analysis of test results.

\section{3) Teachers' psychological capital Scale reliability test}

After items analysis and factor analysis, the researchers divided the official questionnaire into four aspects, and totally 20 questions. To further explore the consistency and stability of the questionnaire, and the question items conducted formal scale reliability test, and the testing result $\alpha$ value is.939 at the aspect of "self-efficacy", and in the hope aspect $\alpha$ value is .916, in the "optimistic" aspect $\alpha$ is .920 and in " resilience " aspect $\alpha$ value is .926 , while the overall scale reliability is .938 , it shows that the reliability of this research tool is good.

\section{B. Teacher Effectiveness Questionnaire SCALE items Analysis}

\section{1) Teaching effectiveness scale items analysis}

Via the SPSS statistical analysis the researchers found that24 questions in "elementary school teachers' teaching effectiveness" t values reached the .000 level of significance, the question items and the total score correlation coefficients were greater than .30, and alpha coefficient do not higher than total reliability alpha value of .972 .

\section{2) Teaching effectiveness scale factors analysis}

From the analysis of "Teachers' Psychological Capital Scale." result, we found that the value of KMO is .910, p $<.001$ reach to the significant level. Teachers teaching effectiveness scale is extremely suitable for factor analysis. In this factor analysis, the overall teachers psychological capital Scale cumulative $70.948 \%$ of the total variance.

\section{3) The reliability test of teachers' teaching effectiveness scale}

In the "Teaching Effectiveness Scale", after analyzing the items and factor, it can be divided into four aspects in the official questionnaire, totally 24 questions. To further ensure the consistency and stability of the questionnaire, the researchers make reliability test on formal scale question items. The testing result shown that: the value of $\alpha$ is .950 in the aspect of teaching philosophy, and in teaching strategies aspect the value of $\alpha$ is .951, and in teaching evaluation aspect the value of $\alpha$ is .953 , and in the class leadership aspect the value of $\alpha$ is .951 , while the overall scale reliability is .958 .

\section{Study Participants and Questionnaire Implementation}

The study makes tteachers in public elementary schools in Chiayi County as the sample of the population, and the numbers of recycled official questionnaires were 280 , the rate of questionnaires recovery is $95 \%$. After recycling the formal questionnaires, the researchers check the situations of answering by each question. The researchers regard missing answer more than 5 questions as the invalid questionnaires, and it not included in the statistics, totally 274 valid questionnaires, the rate of available recycling is $98 \%$. In this study, a survey conducted by the effective sample data, data processing and statistical analysis with SPSS for Windows 19.0 software package program.

\section{THE RESULT OF RESEARCH AND DISCUSSION}

\section{A. The Situation Analysis and Discussion of Chiayi County Teachers' Psychological Capital and Teaching Effectiveness}

1) The degree of the whole teachers' psychological capital perceives is above median level

The average score of the teachers in the elementary school 
teachers psychological capital scale is 3.57 (Table I), and it displays on the degree of the psychological capital scale of Chiayi County Elementary School teachers perception is above median level, it shows that good perceived status for Chiayi County Elementary School teachers psychological capital. Among all, the "self-efficacy" is the better aspect and the lowest score is "resiliency" aspect, deducing at the possible reasons for it, teachers adhere to lifelong learning, continuous self-sophisticated; another aspect is legalization of parental involvement in school affairs, so teachers must face community communication and interaction with parents, teachers' psychological capital became an important factor. To face the education become market-oriented, friendly campus only for students, but teachers seems to be excluded. The unlimited increase responsibilities for teachers and teachers' rights seem to be deprived. It may be the reason for the lowest score of "resiliency".

TABLE I: THE ABSTRACT ANALYSIS TABLE OF TEACHERS' PSyCHOLOGICAL CAPITAL AsPeCtS AND General STATUS

\begin{tabular}{|c|c|c|c|c|c|c|}
\hline Aspect & $\mathrm{N}$ & SUM & SD & $\begin{array}{l}\text { Question } \\
\text { Items }\end{array}$ & & Average \\
\hline Self efficacy & 274 & 22.10 & .61 & & 6 & 3.68 \\
\hline Hope & 274 & 18.12 & .50 & & 5 & 3.62 \\
\hline Optimism & 274 & 17.50 & .53 & & 5 & 3.50 \\
\hline Resiliency & 274 & 13.82 & .51 & & 4 & 3.45 \\
\hline Overall & 274 & 71.31 & .47 & & 20 & 3.57 \\
\hline
\end{tabular}

\section{1) The status of the general teaching effectiveness} consciousness is good.

The average score of elementary teachers' teaching effectiveness is 3.94 (see Table II), it shows that the teaching effectiveness consciousness above the mediate level, and shows Chiayi county elementary teachers' teaching effectiveness consciousness is good. Among all aspect, the highest aspect is "teaching strategy" and got the average score 4.06. The lowest score is "teaching assessment" and got the average score 3.80. The possible reasons may be the promotion of creative teaching and the competition of teaching plan, and advise the multi-cultural teaching strategies to focus the significance of teaching strategies. Furthermore, the elementary schools' classes all belong to normal classes, and it makes the difficulty of teaching assessment and homework design, and the emphasis on teaching and learning activities with the changes, but students' learning outcomes did not promote.

\section{B. The Analysis of Different Background Items of Elementary Teachers' Psychological Capital and Teaching Effectiveness}

\section{1) The analysis of the difference in the different background variable in the psychological capital}

The research shows the great difference in different aspects of serving years, duty, marriage situations, health situation and interpersonal relationship in the psychological capital (Table III). The research shows that teachers who have the longer serving years, the duty of director, marriage, health situation and good personal relationship have better performance in psychological capital.
TABLE II: THE ANAISIS OF TEACHERS’ TEACHING EFFECTIVENESS IN EACH ASPECT.

\begin{tabular}{|l|l|l|l|l|l|}
\hline Aspect & $\mathrm{N}$ & SUM & SD & $\begin{array}{l}\text { Questio } \\
\text { n Items }\end{array}$ & $\begin{array}{l}\text { Averag } \\
\mathbf{e}\end{array}$ \\
\hline $\begin{array}{l}\text { Teaching } \\
\text { philosophy }\end{array}$ & 274 & 19.60 & .54 & 5 & 3.92 \\
\hline $\begin{array}{l}\text { Teaching } \\
\text { strategy }\end{array}$ & 274 & 24.34 & .56 & 6 & 4.06 \\
\hline $\begin{array}{l}\text { Teaching } \\
\text { assessment }\end{array}$ & 274 & 22.82 & .58 & 6 & 3.80 \\
\hline $\begin{array}{l}\text { Class } \\
\text { leadership }\end{array}$ & 274 & 27.94 & .58 & 7 & 3.99 \\
\hline Overall & 274 & 94.62 & .51 & 24 & 3.94 \\
\hline
\end{tabular}

TABLE III: THE ABSTRACT OF THE DIFFERENT BACKGROUND VARIABLE IN THE PSYCHOLOGICAL CAPTICAL OF THE ELEMENTARY SCHOOL'S TEACHER

\begin{tabular}{|c|c|c|c|c|c|c|}
\hline \multirow{2}{*}{ Variable } & \multirow{2}{*}{ group } & \multicolumn{5}{|c|}{ psychological capital } \\
\hline & & SE & $\breve{H}$ & $\mathrm{O}$ & $\mathrm{R}$ & $\mathrm{PC}$ \\
\hline \multirow{2}{*}{ Sex } & male & \multirow{2}{*}{ n.s. } & \multirow{2}{*}{ n.s } & \multirow{2}{*}{ n.s } & \multirow{2}{*}{ n.s } & \multirow{2}{*}{ n.s } \\
\hline & female & & & & & \\
\hline \multirow{4}{*}{ Age } & below 30 & \multirow{4}{*}{ n.s. } & \multirow{4}{*}{ n.s } & \multirow{4}{*}{ n.s } & \multirow{4}{*}{ n.s } & \multirow{4}{*}{ n.s } \\
\hline & between31-38 & & & & & \\
\hline & between39-46 & & & & & \\
\hline & between $47-55$ & & & & & \\
\hline \multirow{3}{*}{$\begin{array}{l}\text { Years of } \\
\text { service }\end{array}$} & below 10 & \multirow{3}{*}{$\begin{array}{l}2>1 \\
3>1\end{array}$} & \multirow{3}{*}{ n.s } & \multirow{3}{*}{ n.s } & \multirow{3}{*}{ n.s } & \multirow{3}{*}{ n.s } \\
\hline & between $11-20$ & & & & & \\
\hline & more than 20 & & & & & \\
\hline \multirow{3}{*}{$\begin{array}{l}\text { Academic } \\
\text { backgroun } \\
\text { d }\end{array}$} & teachers college & \multirow{3}{*}{ n.s. } & \multirow{3}{*}{ n.s } & \multirow{3}{*}{ n.s } & \multirow{3}{*}{ n.s } & \multirow{3}{*}{ n.s } \\
\hline & normal university & & & & & \\
\hline & graduate school & & & & & \\
\hline \multirow{4}{*}{ Position } & teacher director & \multirow{4}{*}{$\begin{array}{l}1>2 \\
1>3 \\
1>4\end{array}$} & & & & \\
\hline & teacher chief & & & & & \\
\hline & teacher advisor & & $\begin{array}{l}1>2 \\
1>3\end{array}$ & n.s. & $1>3$ & $1>3$ \\
\hline & $\begin{array}{l}\text { teacher, but not in } \\
\text { administration }\end{array}$ & & & & & \\
\hline Marriage & unmarried & $2>1$ & $2>1$ & $n_{s}$ & $n s$ & $2>1$ \\
\hline Marriage & married & & & 11.5 . & 11.s. & \\
\hline Interperson & ordinary & & & & & \\
\hline & good & $\begin{array}{l}2>1 \\
3>1\end{array}$ & $2>1$ & $2>1$ & $2>1$ & $2>1$ \\
\hline $\begin{array}{l}\text { relationshi } \\
\mathrm{p}\end{array}$ & great & $3>2$ & $3>1$ & $3>1$ & $3>1$ & $3>1$ \\
\hline & worse & & & & & \\
\hline condition & ordinary & $3>1$ & $3>1$ & $3>1$ & $3>1$ & $3>1$ \\
\hline of health & good & $3>2$ & & & $\begin{array}{l}3>2 \\
4>1\end{array}$ & \\
\hline & great & & & & & \\
\hline & usual area & & & & & \\
\hline location of & remote districts & n.s. & n.s & n.s & n.s & n.s \\
\hline school & special remote & & & & & \\
\hline & below 6 & & & & & \\
\hline The scale & between7-12 & n.s. & n.s & n.s & n.s & n.s \\
\hline of school & between13-24 & & & & & \\
\hline & more than 25 & & & & & \\
\hline
\end{tabular}

SE: Self efficacy

H: Hope

O: Optimism

R: Resiliency

PC: Psychological capital (Overall) n.s: Unreached the remarkable level

The research shows the great challenge in different positions in the overall psychological capital. It shows the great difference in the aspect of psychological capital with different duties. The reason may be more and more task challenges for the directors, and the principal pursuit for the school performance, and the communication with teachers. It makes directors become a sandwich between them. It needs higher psychological capital for this position.

It shows that the score of the serving years above 20 years and 11-20 years is higher than less than 10 year. For the overall teaching effectiveness, it does not have visible differences.

In the overall teaching effectivenessy, it isn't so different to 
the performance of elementary school teachers in different marital status. In "class leadership", married teachers have the better performance than unmarried ones.

The teachers who impose themselves' interpersonal relationship as "great" and "good" have better behavior than those who impose themselves' interpersonal relationship as "ordinary" in psychological capital. Elementary school teacher's different interpersonal relationships have the significant differences. In short, teachers have different interpersonal relationships.

The teachers who think themselves' health condition are "good" performance better than who impose as "worse". Teachers who have remarkable different health condition are also different in psychological capital; that is teachers in different health condition also significant difference in "psychological capital".

The impersonal relationship shows personal EQ and the disclosure of personal accomplishment, good relationships can enhance communication and coordination force, through interaction and sharing, to obtain the support of others, and rich psychological capital. Researchers collate the different background variables of elementary school teachers in the "psychological capital" and the differences shown in the table.

\section{2) The analysis of the difference in the different}

background variable in the effectiveness of the teaching of elementary school's teachers.

From the difference of the comprehensive analysis, researchers found that different background variable of the teaching effectiveness of the teacher's in elementary school (Table V). For the aspects of "teaching effectiveness", "teaching strategy", "teaching evaluation" and "class leadership", it shows that it does not have significant differences between different genders. It shows the great difference, and the female teachers' performance is better than the males'.

Moreover, the possible factors that the "married" teachers' performance is better than those who "unmarried" are the changes after their marriage, the ability of their interpersonal relationship, interaction and reaction are better, through the exchange of the experience or conversion, therefore, the "married" teachers are better than the "unmarried" teachers.

The person who is the "teacher director", teaching effectiveness is better than those who are "teacher chief" and "teacher advisor". Because of the director's position, the policy and educational information can receive earlier and easier, the performance is better in their teaching effectiveness.

Besides, if the teachers' interpersonal relationship is good, the performance of their teaching effectiveness is better than those teachers whose "interpersonal relationship" are normal. The reason is that those who have the good interpersonal relationship will have the good communication with the students, their parents and co-workers. Having the better interaction, it will have the influence and enhance their teaching effectiveness. On the spot of the teaching, we can see that the teacher's good interpersonal relationship will earn the students' love, the students agree and love the teachers, then they will make more effort and have a good performance, and the effectiveness of the teachers will be more higher.

The average of the teaching effectiveness of the schools in the remote area is higher than the special and usual area. It shows that the teachers in "usual area" and "remote districts" performance better than those who are in "specially remote area" in "teaching strategy"

The reason is that the remote schools are at between the urban and rural, and the scale of the school is below 12 classes, and face the low fertility and the pressure of above quota of the reduced class, therefore cause the dangerous awareness, they try to strength the effectiveness of the school to avoid exit and combine, they will show the higher performance of the effectiveness.

TABLE IV: THE DIFFERENCE OF THE COMPREHENSIVE ANALYSIS IN THE DIFFERENT BACKGROUND VARIABLE OF THE TEACHING EFFECTIVENESS OF THE TEACHER'S IN ELEMENTARY SCHOOL

\begin{tabular}{|c|c|c|c|c|c|c|}
\hline \multirow{2}{*}{ Variable } & \multirow{2}{*}{ Group } & \multicolumn{5}{|c|}{ Teaching effectiveness } \\
\hline & & $\mathrm{TP}$ & TS & TA & $\mathrm{TL}$ & TE \\
\hline \multirow{2}{*}{ Sex } & Male & \multirow{2}{*}{$\begin{array}{l}2> \\
1\end{array}$} & \multirow[b]{2}{*}{ n.s } & \multirow[b]{2}{*}{ n.s } & \multirow[b]{2}{*}{ n.s } & \multirow[b]{2}{*}{ n.s } \\
\hline & Female & & & & & \\
\hline \multirow{4}{*}{ Age } & Below30 & \multirow{4}{*}{ n.s } & \multirow{4}{*}{ n.s } & \multirow{4}{*}{ n.s } & \multirow{4}{*}{ n.s } & \multirow{4}{*}{ n.s } \\
\hline & Between31-38 & & & & & \\
\hline & Between39-46 & & & & & \\
\hline & Between47-55 & & & & & \\
\hline \multirow{3}{*}{$\begin{array}{l}\text { Years of } \\
\text { service }\end{array}$} & Below 10 & \multirow{3}{*}{ n.s } & \multirow{3}{*}{ n.s } & \multirow{3}{*}{ n.s } & \multirow{3}{*}{ n.s } & \multirow{3}{*}{ n.s } \\
\hline & Between11-20 & & & & & \\
\hline & More than20 & & & & & \\
\hline \multirow{3}{*}{$\begin{array}{l}\text { academic } \\
\text { background }\end{array}$} & Teachers college & \multirow{3}{*}{ n.s } & \multirow{3}{*}{ n.s } & \multirow{3}{*}{ n.s } & \multirow{3}{*}{ n.s } & \multirow{3}{*}{ n.s } \\
\hline & Normal university & & & & & \\
\hline & Graduate school & & & & & \\
\hline \multirow{4}{*}{ Position } & Teacher director & \multirow{4}{*}{ n.s } & \multirow{4}{*}{ n.s } & & & \\
\hline & Teacher chief & & & $1>$ & $1>$ & 1) 3 \\
\hline & Teacher advisor & & & $\begin{array}{l}2 \\
1>\end{array}$ & $\begin{array}{l}2 \\
1>\end{array}$ & $1>3$ \\
\hline & $\begin{array}{l}\text { Teacher, but not in } \\
\text { administration }\end{array}$ & & & $\begin{array}{l}1> \\
3\end{array}$ & $\begin{array}{l}1> \\
3\end{array}$ & \\
\hline Marriage & $\begin{array}{l}\text { Unmarried } \\
\text { Married }\end{array}$ & n.s & n.s & n.s & $\begin{array}{l}2> \\
1\end{array}$ & n.s \\
\hline Interpersonal & Ordinary & $\begin{array}{l}2> \\
1\end{array}$ & $\begin{array}{l}2> \\
1\end{array}$ & $\begin{array}{l}2> \\
1\end{array}$ & $\begin{array}{l}2> \\
1\end{array}$ & $2>1$ \\
\hline relationship & $\begin{array}{l}\text { Good } \\
\text { Great }\end{array}$ & $\begin{array}{l}3> \\
1\end{array}$ & $\begin{array}{l}3> \\
1 \\
\end{array}$ & $\begin{array}{l}3> \\
1\end{array}$ & $\begin{array}{l}3> \\
1 \\
\end{array}$ & $3>1$ \\
\hline & worse & 3> & & & & \\
\hline The & ordinary & 1 & & $n_{0}$ & $n$, & $n_{0}$ \\
\hline health & good & 3> & n.s & n.s & II.s & 11.s \\
\hline & great & 2 & & & & \\
\hline & Usual area & & $1>$ & & & \\
\hline The location & Remote districts & n.s & 3 & n.s & $\mathrm{ns}$ & $\mathrm{n}_{\mathrm{s}}$ \\
\hline of school & Special remote & 110.5 & $\begin{array}{l}2> \\
3\end{array}$ & & $11 . \mathrm{s}$ & \\
\hline & Below 6 & & & & & \\
\hline The scale of & Between7-12 & & & & & \\
\hline school & Between13-24 & n.s & n.s & n.s & n.s & n.s \\
\hline & More than25 & & & & & \\
\hline
\end{tabular}

TP: Teaching philosophy

TS: Teaching strategy

TA: Teaching assessment

TL: Class leadership

TE: Teaching effectiveness (Overall)

n.s: Unreached the remarkable level

\section{The Relationship between the Psychological Capital and Teaching Effectiveness in Elementary School's Teachers}

There are highly positive correlation between the performance of psychological capital and the teaching effectiveness in elementary school's teachers. (Table V) It means that if the performance of the psychological capital is higher, the performance of the teaching effectiveness is better. 
It means that the higher of the psychological capital, the better of the teaching effectiveness.

TABLE V: THE ABSTRACT OF THE CORRELATION COEFFICIENT IN PSYCHOLOGICAL CAPITAL AND TEACHING EFFECTIVENESS

\begin{tabular}{|l|l|l|l|l|l|}
\hline \multirow{2}{*}{$\begin{array}{l}\text { Psychological } \\
\text { capital }\end{array}$} & \multicolumn{5}{|l|}{ Teaching effectiveness } \\
\cline { 2 - 6 } & $\mathrm{TP}$ & $\mathrm{TS}$ & $\mathrm{TA}$ & $\mathrm{TL}$ & $\mathrm{TE}$ \\
\hline Self efficacy & $.68 * * *$ & $.60 * * *$ & $.61 * * *$ & $.62 * * *$ & $\begin{array}{l}.69 * * \\
*\end{array}$ \\
\hline Hope & $.68 * * *$ & $.62 * * *$ & $.63 * * *$ & $.65 * * *$ & $.71 * *$ \\
$*$
\end{tabular}

TP: Teaching philosophy

TS: Teaching strategy

TA: Teaching assessment

TL: Class leadership

TE: Teaching effectiveness (Overall)

$* * * p<.001$

\section{The Influence between Psychological Capital and}

Teaching Effectiveness of Elementary School's Teachers

The aspects of the psychological capital of the elementary school's teachers have the influence on every aspects and integrity of teaching effectiveness (Table 6). After the analysis, we find that the "Hope" "self efficacy" and "Resiliency" of the elementary school's teachers have the highly prediction on the teaching effectiveness. It shows that Chiayi county's teachers who have the psychological capital will affect the height of the teaching effectiveness. If the teachers want to enhance teaching effectiveness, it will promote the students' learning ability; it has to improve the psychological capital.

TABLE VI: THE ABSTRACT OF THE RESUlt IN THE MULTIPLE REGRESSION ANALYSIS

\begin{tabular}{|c|c|c|c|}
\hline \multicolumn{4}{|c|}{ FIVAL IDIS } \\
\hline $\begin{array}{l}\text { Criterion } \\
\text { variable }\end{array}$ & After entering the regression & $\begin{array}{l}\text { Explanatio } \\
\mathrm{n}\end{array}$ & $\begin{array}{l}\text { explanat } \\
\text { ion }\end{array}$ \\
\hline \multirow{3}{*}{$\begin{array}{l}\text { Teaching } \\
\text { philosophy }\end{array}$} & Hope & .988 & \multirow{3}{*}{$99.1 \%$} \\
\hline & Self efficacy & .002 & \\
\hline & Resiliency & .001 & \\
\hline \multirow{3}{*}{$\begin{array}{l}\text { Teaching } \\
\text { strategy }\end{array}$} & Hope & .986 & \multirow{3}{*}{$98.8 \%$} \\
\hline & Self efficacy & .002 & \\
\hline & Resiliency & .001 & \\
\hline \multirow{3}{*}{$\begin{array}{l}\text { Teaching } \\
\text { assessment }\end{array}$} & Hope & .985 & \multirow{3}{*}{$98.7 \%$} \\
\hline & Self efficacy & .002 & \\
\hline & Resiliency & .001 & \\
\hline \multirow{3}{*}{$\begin{array}{l}\text { Class } \\
\text { leadership }\end{array}$} & Hope & .986 & \multirow{3}{*}{$98.9 \%$} \\
\hline & Self efficacy & .002 & \\
\hline & Resiliency & .001 & \\
\hline \multirow{3}{*}{$\begin{array}{l}\text { Teaching } \\
\text { effectiveness }\end{array}$} & Hope & .507 & \multirow{3}{*}{$59.3 \%$} \\
\hline & Self efficacy & .072 & \\
\hline & Resiliency & .014 & \\
\hline
\end{tabular}

\section{CONCLUSION AND SugGESTION}

\section{A. Conclusion}

For the research, we provide some conclusion below and state separately:

\section{1) The overall performance of the teachers}

Teachers in the elementary school in Chiayi, they perform well in the integrity of the psychological capital, the "self efficacy" is the best. Teachers perform well are in the integrity of the teaching effectiveness and the "teaching strategy" is the best.

2) The performance of the teachers' background variable and the psychological capital

There are some differences in position, the condition of marriage and the condition of health and they have impact on psychological capital of the elementary school's teachers in Chiayi city. The differences in sex, age, academic background, the location of school and the scale of school of the elementary school's teachers, there psychological capital don't have the obvious difference.

\section{3) The performance of the teachers "background variable" and the teaching effectiveness.}

There are some differences in position and interpersonal relationship. They have impact on psychological capital of the elementary school's teachers in Chiayi city. The person who is "Teacher director", their sense of psychological capital is better than those who are "teacher chief" "teacher advisor" and "teacher and administration". However, there are no differences of teaching effectiveness of the elementary school's teachers in sex, age, the years of service, the academic background, marriage and the condition of health, the location of school and the scale of school.

\section{4) The influence of the performance of the psychological capital and teaching effectiveness}

The performance of the psychological capital will have impact on teaching effectiveness, and the higher of the performance of psychological capital, the better performance of the teaching effectiveness. When teachers teach students, they can have the positive hope and optimism to work, and correspond to the Pygmalion effect. If teachers face difficulties and challenges, they will have the resiliency to do. Therefore, their teaching effectiveness would be better.

\section{B. Suggestion}

According to the research's findings and conclusion, we raise some suggestions, and hope to enhance the teacher's psychological capital and teaching effectiveness, and peruse the educational quality and to have the excellent education.

\section{1) Enlarge and develop teacher's psychological capital} and cultivate the teachers' $E Q$

The educational bureau needs to know the effect of the psychological capital to the teaching effectiveness. The researches find that the good or bad interpersonal relationship will affect the strong or weak of the psychological capital, and is the key factor to the high or low of the teaching effectiveness. Therefore, we have to cultivate the teachers to get used to the skill of the communication of the interpersonal relationship, and to deep their positive attitude and their passion on education, to found the course of the interpersonal relationship. The drive of the policy need to take care of the teachers 'internal demand, and to see the teachers and students as integrity, to encourage the teachers' professional promise and found the teachers' psychological capital and changes into enhance the psychological capital of the organizations in school to make a excellent effectiveness of the school. 


\section{2) Hold some activities for teachers and enhance the teaching effectiveness}

The teachers become the transformative intellectuals, and to positively cultivate the attitude of the teachers" "self efficacy" "hope" "optimism" and "resiliency" to promote the better teaching effectiveness. The research shows that the average of resiliency is the lowest; it shows that the teachers have a lot of pressure. The schools hold the social party and group activities, and provide the ways to relax to enhance their resiliency. In addition, through this way their co-workers cultivate the good interpersonal relationship to hold their relationship and identify the school.

\section{3) Found the standard operating procedure to deal with the school's affairs}

If the routine work of the school enhance, it will cause the burden for the administration, the administration of the educational bureau should integrate the things and to help the schools to build SOP to solve the different kinds of challenges The set up of the policy, law and activity of the school need to correspond to the fairness of the procedure and to let the ideas of the teachers can consider in the laws. The SOP can let the school's affairs become easier and enhance the school effectiveness.

\section{4) Make good use of care and develop the level five leadership, authentic leadership and vision leadership}

The teacher of the sense of the interpersonal relationship is better and good, and their performance of psychological capital and teaching effectiveness are better than the normal teachers. The schools need to make good use of care and to mode the relationship between partners. The psychological capital is an internal attitude and affection. The leader of the school need to integrate the level five leadership, authentic leadership and vision leadership to enlighten the promise and energy of the teachers, to arouse their professional passion and lead them to share their experience to enhance their psychological capital and the teaching effectiveness.

\section{REFERENCES}

[1] B. J. Avolio and F. Luthans, The high impact leader: Moments matter in celebrating authentic leadership development, New York: McGraw-Hill, 2006.

[2] F. Luthans and C. M. Youssef, "Human, social and now positive psychological capital management: Investing in people for competitive advantage," Organizational Dynamics, vol. 33, no. 2, pp. 143-160, 2004.

[3] F. Luthans, K. W. Luthans, and B. C. Luthans, "Positive psychological capital: Beyond human and social capital," Business Horizons, no. 47, pp.45-50, 2004.

[4] F. Luthans, C. M. Youssef, and B. J. Avolio, Psychological capital. Oxford, UK: Oxford University, 2007.

[5] M. E.Gist and T. R. Mitchell, "Self-efficacy: A theoretical analysis of its determinants and malleability," Academy of Management Review, no.17, pp.183-211, 1992.
[6] E. Stotland, "Exploratory investigations of empathy," Advances in experimental social psychology, no. 4, pp. 271-313, 1969.

[7] L. Tiger, "Optimism: The biology of hope," In C. Peterson, "The Future of Optimism," American Psychologist, vol. 55, no. 1, pp. 44-55, 2000.

[8] E. Diener and R. A. Emmons, "The independence of positive and negative affect," Journal of Personality and Social Psychology, vol. 47, no. 5, pp. 1105-1117, 1984.

[9] A. Bandura, Self-efficacy: The exercise of control, New York: Freeman, 1997.

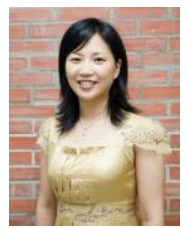

Juei-Hsin Wang is a professor at Graduate Institute of Educational Administration and Policy Development, National Chiayi University, her research interests: education policy, teacher education, e-learning. She is an assistant professor in National Chiayi University, and served as the Section Chief of administrative of Teacher Education Center in 2007. She was promoted to be an associate professor in 2013. She was promoted to be a professor. During these ten years, She engaged in university teaching, research, service and local counseling. From 2009 till now, She is working as the host of professional training center of Teacher Evaluation for Professional Development (Yuling, Chiayi, and Tainan region) of Ministry of Education in Taiwan. From 2004 till now, she has received subsidy from Taiwan's National Science Council (NSC) research grant researches. The author' research are included in educational policy, educational administration, teacher education, sexual equality on education, digital education, and attended conferences to issue papers, and published journals papers etc. more than one hundred papers. She has issued related books or papers, such as gender equality on education, teaching materials and methods for the course of activity of elementary schools, Higher Education system of the U.S., teacher evaluation, and training how to be a scientific teacher etc.

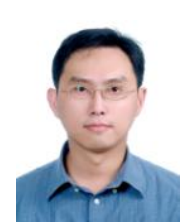

Yen-Ting Chen is an associate professor with the Department of Mathematics Education, National Taichung University of Education. His research interests: mathematics education, e-learning, teacher education. He has been served as an assistant professor in Chung Hwa University of Medical Technology, and has also served as an assistant researcher in National Institute of Compilation and Translation and in National Academy for Educational Research. Now $\mathrm{He}$ is associate professor in the Department of Mathematics Education, National Taichung University of Education. During these ten years, engaged in kindergarten instructor training, mathematics textbooks, mathematics curriculum reviewed and formulated, and researched in mathematics and science teachers how to interaction through internet platform. From 2008 till now, he has received subsidy from Taiwan's National Science Council (NSC) research grant researches. His researches' horizon are included preschool education, math and science teacher education, digital education, and attended conference to issue papers, and published journals papers etc. more than one hundred. The author has issued related books or papers, such as since teacher in Asia.

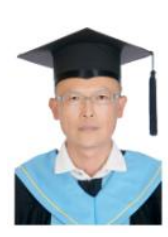

Min Shien Shu now serves as the General Director of Yiren Elementary School at Chiayi-County. He has served as the general director of Yiren Elementary School at Chiayi-County now and he has been a teacher for over twenty three years. He has been committed for teacher research and liked to study teacher professional development, and graduated from Graduate Institute of Educational Administration and Policy Development, National Chiayi University two years ago. 